Provided for non-commercial research and education use. Not for reproduction, distribution or commercial use.

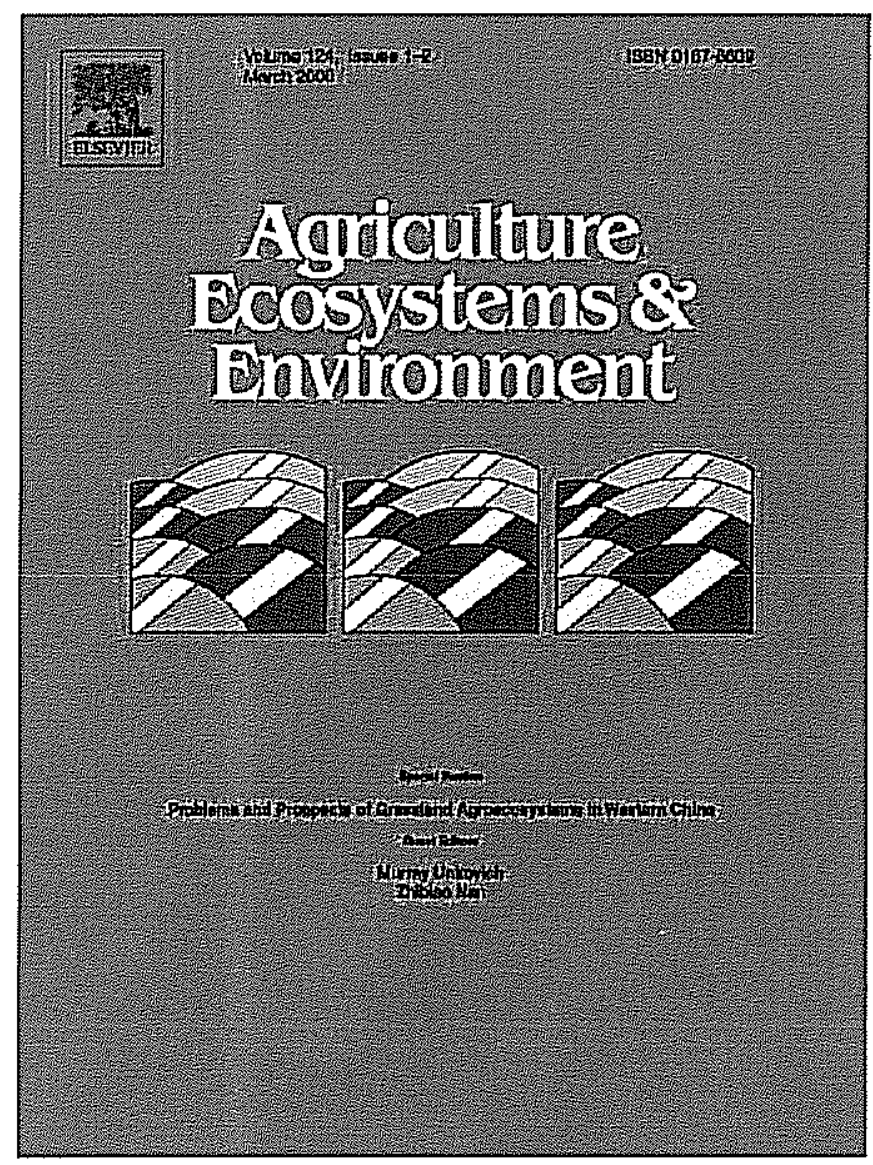

This article was published in an Elsevier journal. The attached copy

is furnished to the author for non-commercial research and education use, including for instruction at the author's institution, sharing with colleagues and providing to institution administration.

Other uses, including reproduction and distribution, or selling or licensing copies, or posting to personal, institutional or third party websites are prohibited.

In most cases authors are permitted to post their version of the article (e.g. in Word or Tex form) to their personal website or institutional repository. Authors requiring further information regarding Elsevier's archiving and manuscript policies are encouraged to visit:

http://www.elsevier.com/copyright 


\title{
In search of sustainable agricultural systems for the Llano Estacado of the U.S. Southern High Plains
}

\author{
V.G. Allen ${ }^{a, *}$, C.P. Brown ${ }^{a}$, E. Segarra ${ }^{a, b}$, C.J. Green ${ }^{a}$, \\ T.A. Wheeler ${ }^{b}$, V. Acosta-Martinez ${ }^{\text {c }}$, T.M. Zobeck ${ }^{\mathrm{c}}$ \\ ${ }^{2}$ Texas Tech University, Lubbock 79-109, USA \\ "Texas A\&M Experiment Station, Lubbock 79403, USA \\ ' USDA-ARS, Plant Stress and Water Conservation Lahomtory, Luhbock, TX 79415. USA
}

Available online 24 Oetuber 2007

\begin{abstract}
Crop production on the Llano Estacado of the Texas High Plains bas used precipitation and supplemental irrigation with water pumped from the Ogallala aquifer at rales that bave far exceeded recharge for many years. Over 20\% of the U.S. cotton (Gossypium hirsutum L.) crop is produced currently in this once vast grassland. Most of this cotton is produced in monoculture systems that are economically risky and contribute to wind-induced erosion and depletion of ground water resources. Although large numbers of cattle are found in this region, little integration of livestock and crop production exists. Integrated crop-livestock systems could improve nutrient cycling, reduce soil erosion, improve water manngement, interrupt pest cycles, and spread economic risk through diversification. Two whole-farm scale systems compared (1) a cotton monoculture typical of the region; and (2) an alterative integrated system that included cotton, forage, and Angus-cross stocker beef steers (initial body weight $249 \mathrm{~kg}$ ). Steers grazed the perennial warm-season grass 'WW-B. Dalıl' old world bluestem [Bothriochloa blathii (Retz) S.T. Blake] in sequence with rye (Secale certale L.) and wheat (Triticum aestivum L.) from January to mid-July when they were sent to the feedyard for finishing. Grass seed were harvested from bluestem in October. Cotton in the alternative system was grown in a twopaddock rotation with the wheat and rye. Cotton was harvested from both systems in October. At the end of 5 years, the alternative system reduced needs for supplemental irrigation by $23 \%$ and for nitrogen fertilizer by $40 \%$ compared with the conventional cotton monoculture. Fewer chemical inputs including pesticides were required by the alternative system. Soil witl perennial grass pasture was lower in predicted soil erosion and was higher in soil organic carbon, aggregate stability, and microbial biomass than soil where continuous cotton was grown. Profitability was greater for the alternative system until cotton lint yields reacled about $1500 \mathrm{~kg} \mathrm{ha}^{-1}$ for the continuous cotton system. Differences between the systems became larger as depth to ground water increased. Systems that are less dependent on supplemental irrigation and less consumptive of non-renewable resources and energy-dependent chemical inputs appear possible, but further improvements are required to ensure sustainability of agricultural systems for the future in the Texas High Plains.
\end{abstract}

Publisbed by Elsevier B.V.

Keytords: Water; Aquifers; Cropping and livestock systems: Grazing systems: Suil qualily

\section{Introduction}

The Llano Estacado of the Southern High Plains region of the U.S. is both a very ancient and a very young region; old in terms of evolution of its geology and ecology and young in terms of conversion of this ecosystem by European

\footnotetext{
* Corresponding author.

E-mail addners: felician@ttu.edu (V.G. Allen).
}

settlement to a drastically altered, crop dominated ecosystem. This region is also a story about water. Overlying the southern end of the Ogallala Aquifer, water for irrigation has enabled this area to become one of the largest regions of intensive agricultural production on carth. Today, that water is disappearing at an alarming rate. The Ogallala Aquifer is the most intensively used aquifer in the U.S. providing $30 \%$ of the total withdrawals from all aquifers for irrigation (Maupin and Barber, 2005). Without question, the future for 
this region will not be a continuation of past practices. Water in sufficient quantities will not be available to support the irrigation practices and cropping systems that came to characterize this region during the last century. If the economy and productivity of this region are to be sustained into the future, new practices and agricultural systems that are less consumptive of natural resources are essential. In 1997, a multidisciplinary tenm of individuals representing university scientists, practitioners, industries, government agencies, and local businesses designed research to compare an integraled crop/livestock system with a monoculture cotton (Gossypium hirsutum L.) production system. Currently, between 20 and $25 \%$ of the colton produced in the U.S. is grown in this region, primarily in monoculture systems. Thus, the objective was to test whether the integrated system provided more sustainable production in terms of profitability, irrigation water use, other energydependent inputs, and impact on natural resources than the cotton monoculture. This research is ongoing and some results have been published (Allen et al., 2005; AcostaMartinez et al., 2004; Collins, 2003). These results are reviewed and presented in this paper along with preliminary results from later ycars.

\subsection{History and physiography of the Texas High Plains}

To understand the challenges and design solutions for this region, it is necessary to appreciate both its history and its physiography. The Greal Plains of North Americn comprises the vast interior region to the east of the Rocky Mountain chain and extends from Texas into Canada. The Llano Estacado or 'Staked Plains' of Texas is geographically part of the Great Phins and is located at the southern end primarily in Texas. It is best described as a nearly level, trecless, semiarid region (Webb, 1931). The relative flatness of the land is one of its most dramatic features. Slightly tilted, elevations range from $1372 \mathrm{~m}$ in the west to $823 \mathrm{~m}$ in the southeast but the vast expanse of the region makes this change imperceptible (Urban, 1992). The name is suggested to derive from the possibility that carly Spanish explorers were so disoriented by the featureless landscape that they drove stakes into the ground to mark their route (Brooks et al., 2000).

The High Plains are a remnant of a vast alluvial plain formed by sediments deposited by ancient rivers that flowed enstward from the then-forming Rocky Mountains (Wecks and Sun, 1986). The source of these sediments was debris for even as the mountains were being thrust upwards the forces of erosion were beginning to tear them down. These sediments were deposited in a smooth coalescing alluvialfan of vast extent (Johnson, 1931). The uplift of the Rocky Mountains occurred around 65 million years ago. Around 10 million years ago, during the Quaternary or late Tertiary age, the water-bearing sands of the Ogallala Aquifer were deposited across the region. This is the major water-bearing unit of the Texas High Plains (Weeks and Gutentag, 1984).
The formation is found at varying depths at or near the land surface throughout most of the region with at least $80 \%$ of the water found within $120 \mathrm{~m}$ of the surface (Urbin, 1992). The quality of this waler is suited for most purposes and its presence has shaped the use and economy of the region during the past century.

\subsection{Climate, soils, plants, and animals}

Climatically, the region is semiarid, having a dry steppe climate with mild winters. Annual precipitation over the area ranges from about $355 \mathrm{~mm}$ in the west to about $559 \mathrm{~mm}$ at the eastern edge. Precipitation occurs often as thunderstorms that occasionally produce tornadoes, high winds, and hail. Intensity of rainfall events leads to runoff and localized flooding. About two-thirds of the annual rainfall occurs just before or during the growing season (Fig. 1). May and September generally receive peak rainfall amounts with very dry conditions prevailing during winter from October through April. The region has one of the highest percentages of sunny days in the continental U.S. but killing frosts can occur in spring following periods of mild temperatures that, along with wind and hail, can stress both plants and livestock. The nearly constant wind that sweeps across the plains has desiccating effects on young crops and contributes to wind erosion of soils. March to May is the windiest period generally and coincides with the planting time for crops that predominate in the region.

Soils of the Llano Estacado are mostly sandy loams, clay loams, with some areas of clayey loams of uniform texture (Livingston, 1952). Created from the Qunternary Acolian sands and loess sheet of the Blackwater Draw Formation (Lee et al., 1994), generally they are fine-textured and very susceptible to wind and water erosion. At varying depths throughout the region a thick layer of caliche, a clayey-limey stratum, occurs that linits root penetration (Brooks et al., 2000).

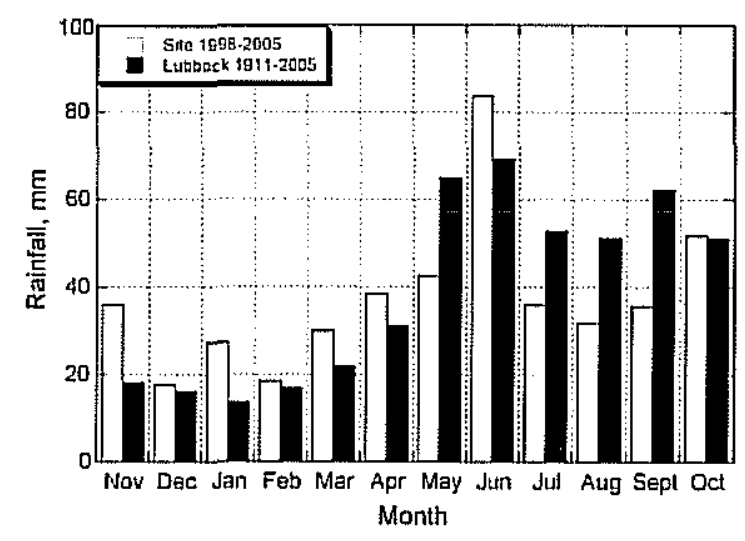

Fig. 1. Precipitation during 7 year at site of comparison of a totton monoculture and an infegrated cotlon-forage-livestock system and the long-lerm average (1911-2005) for Lubback, TX (about $16 \mathrm{~km}$ fron resean'll site). 
Vegetation on the Llano Estacado evolved as a grassland variously characterized as mixed-prairic, short-grass prairic, and in some locations as tall-grass prairie (Gould, 1975). Eventually, the major species that evolved included buffalograss (Buchloe dactyloides) along with blue grama (Bouteloua gracilis) and sideonts grama (Bouteloua curtipendula). Low total seasonal precipitation and/or uneven distribution, and frequent fires contributed to the development of this grassland system. Although virtually treeless, sand sagebrush (Artemisia filifolia) and mesquite (Prosopis glandulosa) are common invaders, especially in the southern areas. These unique grasslands supported a wide diversity of animals. Although most of the large Pleistocene mammals became extinct between 11,000 and 10,000 years ago, in more modern times, the Llano Estacado was home to bison (Bison bison), pronghorn (Antilocapra americana), wolves (Camis lipus), coyotes (Canis latrans), and with Spanish exploration during the 1600 s, the horse (Equhts caballus) was reintroduced into its ancestral home.

\subsection{Human influence}

Human occupation of this region is known to date back over 11,000 years (Brooks et al., 2000). Paleolithic hunters inhabited these plains to the eastern slopes of the Rockics. These 'Big Game Hunters' were followed by woodland and river-valley cultures that stbsisted on small game and wild plants. Around 1500 years ago, evidence of a more agrarian society exists where the people grew corn (Zea mays), beans (Phaseolus spp.), squash (Cucurbita spp), and tobacco (Nicotiana tabacum) along the river bottoms although hunting continued to be important. In more recent time, the Llano Estacado became hone to Apaches, Comanches, and the Kiowas. Apaches probably arrived in this region about 1500 (Hyde, 1959). The fierce Comanche dominated the Southern High Plains by the middle of the $18 \mathrm{th}$ century (Noyes, 1993).

With the arrival of Spanish explorers in the 16th century, the fate of the region was irrevocably altered. These early explorers brought with them horses and guns and the course of history began to change. The introduction of the horse greatly improved the mobility of the native peoples and the Comanche particularly became the great horsemen of the plains (Noyes, 1993). Alternating among trade, cooperation, conquest, and division, the forces of European settlement were gradually imposed into this region. Although under treaty with the U.S. Government, hunters entered the region and began massive slaughter of the vast herds of buffalo to supply demands of Eastem markets for buffalo hides. In 1874 , the same year that barbed wire was patented, Indian tribes gathered in one last but unsuccessful effort to drive the encroaching buffalo hunters from their homelands (Izzard, 1993). By the 1880 s the Native Americans effectively had been moved to reservations to the north. Cattle had replaced the buffalo as the predoninant grazing animal and the region became dominated by large cattle ranches.
Until the late 1880 s, would-be settlers shunned the Texas High Plains primarily because of lack of reliable and adequate water. By the late 1800 s people entering the region brought with them the technology to hand-dig wells and pump the water from the aquifer that by then was known to exist just a few feet below the surface of the land. Windmills provided the means to pump water in sufficient quantities for livestock and for growing of food and also supplied water to replenish the steam locomotives that had begun to cross the region. By the 1930 s and $1940 \mathrm{~s}$, with rural electrification as well as gasoline engines, irrigated agriculture expanded in the region. The water was thought to be an inexhaustible supply recharged with snow-melt from the Rocky Mountains. By the 1970 s, $69 \%$ of the total irrigated crop land in Texas was located in the High Plains (Urban, 1992). The Texas High Plains also had become home to a vast cattle feeding industry that today accounts for about $25 \%$ of all the cattle on feed in the U.S.

Studies conducted during the 1970 s began to reveal the decline in water in the aquifer and concerns mounted over the future use of this resource. Improved irrigation technologies developed during the last part of the 20th century grently reduced the waste of water pumped for irrigation but more wells continued to be built adding to the total withdrawal of water. By the close of this century, a realization was inescapable that water was becoming a major concern to the sustainability of the systems that had been implemented in this region over the past 100 years. Today, over $95 \%$ of the water extracled from the aquifer is used for irrigated agriculture. Withdrawal rates documented by the High Plains Underground Water District in the 15 counties surrounding Lubbock, Texas during the period of 1993-2003 showed a drop of $399 \mathrm{~mm}$ per year in the aquifer (High Plains Underground Waler Conservation District No. $1,2003)$. Recharge to the aquifer is minimal, however, with most estimates suggesting less than $25 \mathrm{~mm} /$ year (Brooks et al., 2000; Gutentag et al., 1984) to a maxinum estimate of $50 \mathrm{~mm} /$ year in some areas (High Plains Underground Water District, personal communication). Less than $1 \%$ of the precipitation percolates through the root zone effectively making this a non-rechargeable water source (Brooks et al., 2000).

Thus, today, the Llano Estacado reflects the results of millions of years of geomorphologic processes, at least 12,000 years of occupntion by Native Americans, but only a century or so of the impact of modern civilization. Over millions of years, plants and animals evolved in this region to form a stable, interdependent, and resilient ecosystem (Brooks et al., 2000). Native Americans followed nomadic and locally agrarian lifestyles over thousands of years of occupation. During the last 100-125 years, settlement largely by Europeans has resulted in disturbance of nearly every hectare of this once vast grassland. Water, once considered to be an inexhaustible resource, is now known to be declining at a rate that has already left many wells dry and crop production increasingly vulnerable. 
Today, over 5 million ha of the High Plains have been developed for cultivation, with ncarly half of the area being irrigated with water from the Ogallala aquifer. About 20 $25 \%$ of the total U.S. cotton crop is produced in this region with over 1.5 million ha planted annually (USDA, 2003; TASS, 1999). Over the past 20 years, a cotton monoculture has developed due to low grain prices, increased cost of irrigation, the U.S. government farm programs of 1985 and 1990, and historically a lack of insect pests. Recent changes in agricultural policy raise questions about the continued profitability and financial viability of current cropping practices. Cotton has been the main row crop with dependable economic profit. However, the cotton monoculture also has increased producers' cash-flow problems and their vulnerability to crop failure due to lack of diversification of agricultural enterprises. Traditional cotton production systens allow nearly $50 \%$ of the total water applied to be wasted to runoff and evaporation, reduce natural soil tilth and fertility, and increase susceptibility to wind-induced soil erosion. Cover crops are grown primarily in the Southern High Plains in irrigated cotton systems where the soil has a high sand content, and blowing sand is a serious constraint to early cotton establishment. The cost in water of cover crops can be high, and they have no recognized economic benefit other than to reduce wind damage to the subsequent cotton. In areas where blowing sand is less of a problem or under dryland cotton production, cover crops are rarely grown. The potential for grazing cover crops by livestock is virtually unknown.

Texals leads all other states in the U.S. in numbers of beef cattle with the High Plains region including 8 of the 10 leading counties (USDA, 2003; TASS, 1999). The Texas High Plains also has the highest concentration of cattle in feedlots in the U.S. (TASS, 1999). About 5.5 million head of stocker catle are shipped into the High Plains each autumn, primarily to graze wheat. (Triticum aestivum L.) before entering feedlots. With grazing centered largely around wheat, marketing strategies for cattle are severely limited. Changes in farm programs now allow for use of other small grains and provide opportunities to extend grazing seasons.

Integrating crop and livestock production can improve total productivity and nutricnt management while reducing needs for pesticides (Allen ct al., 1994, 1997; Fontenot et al., 1997). Crop rotation and use of cover crops have long been known to reduce erosion and improve productivity. The importance of crops, forages, and livestock to the Texas High Plains highlights the need to develop systems that enhance profitability, improve conservation of soil and water resources, and expand marketing opportunitics for a more sustainable agricultural system. Duc to its impact on natural resources, the cotton monoculture currently in place is not a sustainable system. Although the native grassland/grazing system was sustainable for millions of years, the level of production is inadequate to generate either sufficient income or animal products to make this a viable option. As grazing systems are intensified there is a parallel increase in management, water use, fertilizer, pesticides, and other inputs. The need is to find viable systems that can be integrated for crop, forage, and livestock production such that their complimentary benefits would allow for a more sustainable use of water and soil while maintaining an appropriate level of agricultural production.

Research that began in 1997 is being conducted to compare and evaluate productivity, profitability, and impact on natural resources of (1) a cotton monoculure system managed by current, recommended technology and (2) an integrated cotton-forage/livestock system. Both systems used a sub-surface drip irrigation system to maximize efficiency of irrigation water use. This paper presents a review of this ongoing research.

\section{Finding more sustaimable agricultural systems in the Texas High Plains-A review of current research}

\subsection{Experimental area}

The research site is located in Northenst Lubbock County and is part of the Llano Estacado or the Sonthern High Plains [101 $47^{\prime} \mathrm{W}: 33^{\circ} 45^{\prime} \mathrm{N} ; 993 \mathrm{~m}$ elevation]. The landscape is characterized by nearly level soils with 0-1\% slopes. Soils are Pullman clay loam (fine, mixed, superactive, thermic Torrertic Paleusiolls). The research area is defined by the dry steppe climate and mild winters typical of this region (Allen et al., 2005; Fig. 1). Mean long-term annual precipitation is about $465 \mathrm{~mm}$ with most of the precipitation occurring from April through October. Weather data including precipitation, wind speed and direction, relative humidity, solar radiation and temperature were recorded at the site by a Campbell Scientific $21 \mathrm{X}$ micro logger weather monitoring station. A full description of the research methods and the results of the first 5 year were given by Allen et al. (2005), thus, only a brief review is provided here. This ongoing resenrch was initiated in 1997 with 2005 representing the 8th year.

Two systems were compared; (1) a conventional continuous cotton system and (2) an alternative integrated cotton/forage/livestock system (Fig. 2). There were three replications of each system in a complete randomized block design. Effects of systems on animal performance, cotton yield, forage yield, soil compaction, soil fertility and other measurements were analyzed using a model that tests effects of system, replication, year and their interactions (Stecl and Torric, 1960). Each replication in the continuous cotton system includes 0.25 ha and each replication of the alternative system comprises 4 ha for a total of 12.75 ha in the experimental aren. For each system, application of fertilizers was based on soil test results and pesticides on recommendations of Integrated Pest Management Specialists.

An underground drip irrigation system was installed and each individual paddock and field replication for both systems was equipped with a turbine water meter to measure 

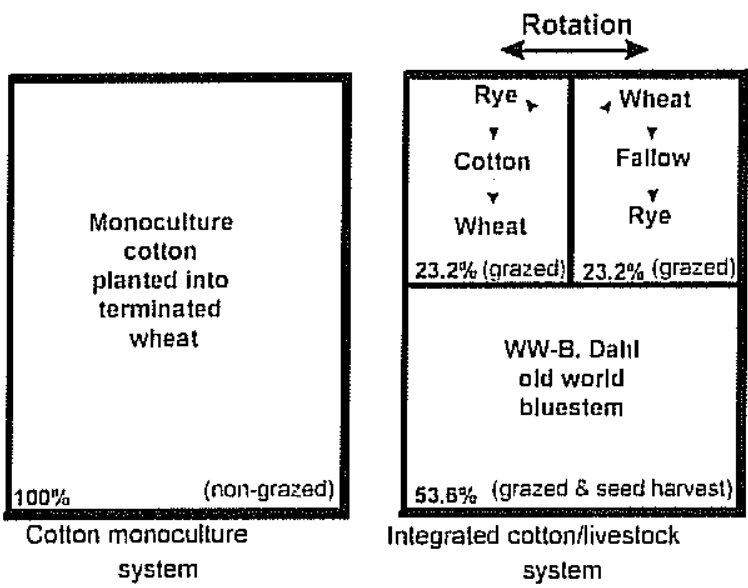

Fig. 2. System design for a callon monoculture and an integrated cottonforage-livestock system (from Allen at al., 2005).

total water applied. Drip tapes were located on $1-\mathrm{m}$ centers and were buried approximately $0.36 \mathrm{~m}$ deep with injection molded emitters on $0.6 \mathrm{~m}$ centers. Irrigation was applied to supplement precipitation as needed to ensure forage for grazing (Allen et al., 2005). Irrigation of cotton was based on evapotranspiration $\left(\mathrm{ET}_{0}\right)$. Percentage $\mathrm{ET}_{0}$ was culculated as a percentage of reference crop evapotranspiration (Allen et al., 1998) and modified according to The ASCE Standardized Relerence Evapotranspiration Equalion (EWRI, 2001).

\subsection{Two irrigated systems compared}

\subsubsection{Contintous cotton system}

A cover crop of wheat was planted each autumn in furrow bottons with listed rows over the drip tapes. In spring, whent was chemically terminated by applying Roundup ${ }^{\text {(3) }}$. Paymaster 2326RR' cotton was planted about 15 May each year into the raised beds between the rows of terminated wheat plants. Four applications of $\mathrm{N}$ were made to cotton during the growing season at various stages of development. Nitrogen was applied through the drip tapes. Pesticides and other chemicals were applied as indicated by presence of insects and growth of the plant. Cotton was harvested with a cotton stripper in autumn. Total weight of cotton produced was obtained in the field at the time of harvest. Immediately following cotton harvest, wheat was again planted into the furrow bottoms between the listed rows.

\subsubsection{Alternative crop/livestock system}

For this system, approximately one half of the total system land area was established in the perennial warmseason grass 'WW-B. Dahl' old world bluestem [Bothriochloa bladhii (Retz) S.T. Blake: Fig. 2]. This grass provided both a seed crop in October and was grazed by steers from January to July. The remaining half of this system was divided into two equal sized paddocks of
0.92 ha each for rotation of rye (Secale cereale L.), cotton, and wheat. 'Maton' rye was planted in carly September. Cattle grazed rye as growth of forage permitted until early April. Rye was then chemically terminated and provided the cover crop for no-till planting of Paymaster 2326RR cotton. Following cotton harvest in autumn, 'Lockett' wheat was no-till planted into cotton stalk stubble. Wheat was grazed out by steers in spring usually ending in May to early June. This paddock was then fallowed until rye was planted the following September. Thus, because there were two paddocks in rotation, cotton alternated each year between the paddocks and both rye and wheat were available for grazing by steers each winter and spring. Application of fertilizers, pesticides, plant growth regulators, and harvesting of cotton was as described for the continuous cotton.

Angus and Angus $X$ Hereford steers (mean body weight $249 \mathrm{~kg}$ ) began grazing in January. During winter, steers grazed primarily slockpiled dormant old world bluestem. Additionally, steers grazed first the rye, later the wheat pasture as available, and finally spring growth of old world bluestem. The grazing method used was sequence grazing among the various forage species but steers were continuously stocked during the time they grazed the individual forages. Steers were supplemented with $34 \mathrm{~kg}$ of a $41 \%$ crude protein while primarily grazing dormant warmseason grass. Assuming 20\% retention of the $\mathrm{N}$ by the steer and no losses to volatilization or leaching, this would have contributed about $4 \mathrm{~kg} \mathrm{Nha}^{-1}$ annually to the old world bluestem and rye pastures as they were alternately grazed. Supplementation stopped before whent pastures were grazed. Because steers remained on pastures, all manure and urine was recycled within the system. By mid-July, steers were moved to the feedyard for finishing and were fed a conventional milo (Sorghm bicolor)-based feedlot diet.

Steers were implanted with the growth hormone implant Ralgro (Schering-Plough Animal Health Corp., Union, NJ) at 90-day intervals during the grazing season. Salt was provided ad libitum. Steers were handled under an Animal Care and Use Protocol approved by the Texas Tech University Aninal Care and Use Committee. Steers were weighed initially, and at 28-day intervals throughout the grazing season.

Detailed records on input use and tillage operations were utilized to develop cost and return budgets for the components in both crop production systems (see Allen et al., 2005). The cost of production portion of these budgets was composed of variable and fixed costs. Variable costs accounted for the cost of all preharvest and harvest inputs used, and capital costs associated with the use of these inputs. Fixed costs accounted for the costs associated with the ownership of machinery and equipment, irrigation systems related costs, and land charges. Irigation system related charges assumed the installation of a sub-surface irrigation system for a representative 50-ha irrigated farm in the Texas High Plains. Due to the farm to farm variability of 
pumping lift, four commonly found pumping lifts in the Texas High Plains were used $(45,60,75,90 \mathrm{~m})$.

Within each system, total cotton and/or forage production and animal production were measured. Inpuls of water, fertilizers, pesticides, seeds, labor, and mechanical and energy inputs were recorded. For cotton, yield and quality of lint and seed were determined. Total water applied to each cropping sequence was determined using rain gatuges lor natural precipitation and meters, described above, for measurement of irrigation water. The overall systems were being compared as well as change over time within systems in terms of total inputs, product yield and quality, prolitability, and impact on water and soil resources. Where differences existed among systents, components were examined further in attempts to understand why these differences occurred.

\section{Results}

During this research, precipitation has averaged above normal in November, January, March, April and June and below normal during the summer months of July, August, and September (Fig. 1). In Year 1, the establishment year. only $292 \mathrm{~mm}$ of precipitation was received between September 22, 1997 and November 21, 1998. Precipitation during Year 2 through 5 was below normal ( $446 \mathrm{~mm}$ vs. the 470 -mm long-term average) with Year 6 being the second driest year on record for this region (22 $4 \mathrm{~mm}$ ) with $304 \mathrm{~mm}$ measured at the site. Temperatures during this period were high, compared with the long-term average for this region. Precipitation during Year 7 exceeded most historical records for the region and was $687 \mathrm{~mm}$ at the resenrch site.

Crop water use has reflected precipitation and differences in water use efficiency among the plant species. During the 7 years of this research following the establishment year, irrigation water use has averaged about $25 \%$ less for the integrated crop-liveslock system than the monoculture cotton system (Table 1). This reduction in water use was due primarily to the water use efficiency of the warm-season perennial grass which represents half of the land area within this system. Water use by the cotton component in the alternative system was higher $(P<0.01)$ than water use by the conventional cotton system during the first 5 years (Allen et al., 2005) but has been similar during years 6 and 7 (data not shown). Differences in water use were duc primarily to irrigation required to gerninate cotton in the rye stubble where placement of seed was not always directly over drip tapes.

Rye used more $(P<0.05)$ water than the old world bluestem per day of grazing. Furthermore, in some years rye has used more $(P<0.05)$ water than wheat because of the differences in time of planting and growth in relation to scasonal distribution of precipitation. Water use efficiency of these cool-senson $\mathrm{C}_{3}$ grasses was expected to be lower than warm-season $\mathrm{C}_{4}$ grasses because of their metabolism.
Table 1

Irrigation water, colton lint yield, net returns above varinble costs of production and net returns above variable cosis per $\mathrm{m}^{3}$ of irrigation waler of a cotton monoculture and an integrated colton-forage-livestock system (data adapled from Allen et al., 2005)

\begin{tabular}{cccr}
\hline Item & $\begin{array}{l}\text { Monoculture } \\
\text { colton }\end{array}$ & $\begin{array}{l}\text { Integrated } \\
\text { system }\end{array}$ & S.E. \\
\hline $\begin{array}{ccc}\text { Irrigation water (mm) } \\
1999-20102\end{array}$ & 481 & $372^{* *}$ & 7 \\
2003 & 420 & 334 & 19 \\
2004 & 296 & $145^{* *}$ & 26 \\
Cotton lint yield (lig ha & 1 ) & & \\
$1999-2002$ & 1036 & 1062 & 29 \\
2003 & 1750 & 2180 & 141 \\
2004 & 1555 & $1300^{\prime}$ & 66 \\
Net returns above variable costs & & \\
$1999-2002$ & 190.91 & 362.17 & \\
2003 & 958.06 & 783.58 & \\
2004 & 928.82 & 459.12 & \\
\hline
\end{tabular}

"* Indicates difference between means witlin a row $(P<0.01)$.

Indicates difference between means $(P<0.06)$.

it Pumping depth was $90 \mathrm{~m}$. Prices used were: colton lint $(\$ 1.21 \mathrm{~kg} \mathrm{~J})$; old world bluestem sied (\$39.60 kg ${ }^{1}$ PLS); steers (\$1.92 $\left.\mathrm{kg}{ }^{1}\right)$; returns do not include any government payments.

Cotton yield (Table 1) and quality during the first 5 years were similar between the two systems. The cotton variety used during these years was Paymaster 2326RR and yields averaged about $1050 \mathrm{~kg} \mathrm{ha}^{-1}$. At the time this research began, this variety of cotton was widely in use in the Texas High Plains. By 2003, growers in the region had largely changed varieties to longer staple, picker-type cotton. Thus, in 2003, the variely of cotton used in this research was changed to reflect grower use and was 'FiberMax 989BR'. Yield of both the monoculture cotton and cotton in the integrated system increased. In 2003, cotton yield did not differ $(P<0.17)$ between the two systems. The 2003 growing season was one of the driest years recorded for this region. In 2004, precipitation was unusually high and temperatures were lower. In this year, the monoculture cotton tended $(P<0.06)$ to out-yield cotton in the integrated system but yields from both systems were lower than in the previous year (1558 vs. $1300 \mathrm{~kg} \mathrm{ha}^{-1}$, respectively).

Steers grazed pastures from January to July and then were moved to the feedlot for finishing. Animal performance during the pasture and feedlot phases met and exceeded expectations. From 1999 (the first year cattle were in the system) to 2004 , daily gains of steers averaged about $0.8 \mathrm{~kg}$ with total seasonal gains on pasture of about $150 \mathrm{~kg}$. Steers spent 185 days on pasture and 138 days on the feedlot. Daily gains during the finishing period averaged $1.5 \mathrm{~kg} \mathrm{day}^{-1}$ for a total gain of $206 \mathrm{~kg}$. Steers averaged $597 \mathrm{~kg}$ at the slaughter facility with a hot carcass weight of $369 \mathrm{~kg}$ and graded $59 \%$ choice with a $64 \%$ dressing percentage. Total feed consumed per steer was $1623 \mathrm{~kg}$ with a conversion rate of $8.5 \mathrm{~kg} \mathrm{feed/}$ $\mathrm{kg}$ gain (as fed basis). Tolal cost per $\mathrm{kg}$ gain was US\$ 1.11.

Following the establishment year through 2004, no bay feeding has been required and steers have never left the 
pastures until moved to the feedlot. The old world bluestem provides dormant winter pasture. In addition to this feed source for stocker cattle, when a protein supplement was provided, this grass has excellent soil covering properties and stood up well to continuous grazing by steers during the winter. It also provided a place to accommodate steers when soils were too wet to graze the small grain pastures. Additionally, the tall grass likely provided some degree of shelter from the cold and wind. The old world bluestem was providing the majority of the grazing days with rye and wheal serving as complementary grazing. Averaged over 1998-2002, grazing days for old world bluestem, rye, and whent were 122 (S.D. $=29$ ), 33.5 (S.D. $=8)$, and 25.3 (S.D. $=7$ ), respectively (Allen et al., 2005).

In October, seed were harvested from the old world bhuestem. Secd yields have ranged from 0 to about $50 \mathrm{~kg}$ PLS/ ha. This old world bluestem species produces seed primarily once in autumn and delayed seed maturity can prevent harvest before a killing frost. Likewise, strong winds and rain can result in seed shatter preventing secd harvest. More research is needed to optimize yield and quality of seed including effects of grazing, timing and amount of irrigation, and fertility requirements. Given the high input and low return of the cotton crop, it may be more profitable to use the limited irrigation resource on the bluestem rather than attempting to sustain a cotton crop in this particular comparison. Potential of other forage crops and seed production should be explored. However, the value of the forage or seed crop or the animal product resulting from consumption of irrigaled forage must be evaluated carefully for economic profitability and justification of water use. Value in terms of soil health, energy savings, air and water quality, and related income including carbon sequestration, wildlife habitat, ecotourism, hunting and fishing, and esthetic values should also be considered in comparing alternative land uses.

The continuous cotton system has required more inputs of chemicals including nitrogen fertilizer, pesticides, and plant growth regulators in all years than the alternative system. Chemical inputs for cotton production per se generally were similar between the two systems but because cotton represented only about $25 \%$ of the alternative system, the overall systems inputs were lower compared with the cotton monoculture system. Nitrogen fertilizer has been reduced about $40 \%$ by the alternative system. This represented not only a lower economic cost but a lower energy input for the alternative system compired with the cotton monoculture. The manufacture of nitrogen fertilizer is an energy expensive process.

Chemical inputs to small grains included only nitrogen fertilizer and the herbicide Round-up needed to terminate ryc for no-till planting of cotton and to suppress weeds lollowing graze-out of wheat. Following establishment, the perennial warm-season grass pasture has required no input of chemical other than nitrogen and some phosphorus fertilizer. Grazing of the old world bluestem and its competitive ability has largely prevented weed encroach- ment while non-grazed, caged areas demonstrated altered plant morphology with more clump-1ype growth and greater weed encroachment (Duch-Carvallo, 2005).

In autumn of 1998, boll weevils (Anthonomus grandis) were placed in emergence cages in two types of potential habitals; i.e. old world bluestem and in terminated rye/ cotton. Results indicated that weevils were capable of surviving a mild winter in either habitat. The difference between the two habitats was not considered significant and the percentage survival was considered to be very low (2.67 and $2.83 \%$, respectively).

Soil-borne disease potential was close to zero at the beginning of this research (Allen et al., 2005). In autumn of 1999, there were similar numbers of nematodes in the soil between the two systems and among the cropping components in the alternative system. No soil-borne fungal diseases at measurable levels were present at the initiation of the project and, in general, disease potential remained low.

At the end of 5 years in this research, total soil $\mathrm{N}$ (about $1.0 \mathrm{~g} \mathrm{~kg}^{-1}$ soil) remained similar between the monoculture cotton and the integrated crop/livestock system (AcostaMartinez ct al., 2004). Soil pH was also similar and was about 8.0. Soil organic carbon was higher in the perennial grass pastures $\left(13.5 \mathrm{~g} \mathrm{~kg}^{-1}\right.$ soil) than in the continuous cotion $\left(9.0 \mathrm{~g} \mathrm{~kg}^{-1}\right.$ soil) in the surface $0-5 \mathrm{~cm}$ of soil (Acosta-Martinez et al., 2004). Their work also showed that soils with the perennial grass pasture exhibited higher soil aggregate stability, soil microbial biomass, microbial biomass $N$, greater numbers of soil protozoa, and greater soil enzyme activities than in the continuous cotlon system. Alternating cotton with small grains in the 2-paddock rolation also influenced several of these soil parameters but the effects depended upon the stage of the rotation.

The perennial grass pastures exhibited lower soil loss from wind and water erosion than the monoculture cotton system (Collins, 2003). Soil loss was predicted using the Universal Wind Erosion Equalion and the Revised Universal Soil Loss Equation (Fryrear et al., 2001). Soil loss in perennial pasture was less than $0.5 \mathrm{Mg} \mathrm{ha}^{-1} \mathrm{year}^{-1}$ while that in the continuous cotton exceeded $19 \mathrm{Mg} \mathrm{ha}^{-1}$ year $^{-1}$ but was less than $7.5 \mathrm{Mg} \mathrm{ha}^{-1}$ year $^{-1}$ in the cotton component of the integrated system where cotton was notill planted in rotation with small grains (Collins, 2003).

Soil compaction is of concern from both animal and mechanical traffic in agricultural systems. In Virginia, Morris et al. (1998) demonstrated that grazing a rye cover crop in spring for as little as 2d increased soil compaction at the time the following corn (Zea mays) crop was established but did not reduce corn yields. Within the current systems research, Duch-Carvallo (2005) found that steers grazing rye and wheat in the integrated system increased soil compaction during grazing events compared with non-grazed areas. By the end of each year, however, grazed areas returned to non-grazed compaction levels.

Results from the first 4 years following the establishment year show that at observed levels of productivity for crops 


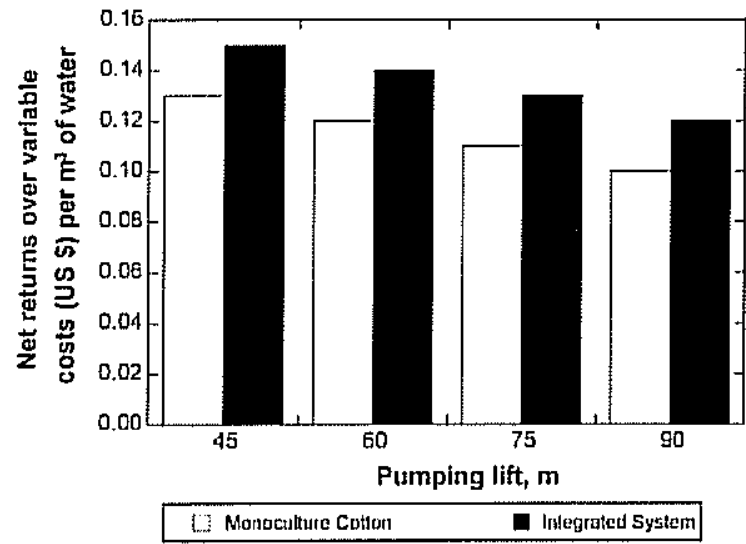

Fig. 3. Net returns above variable costs of production per cubic meter of irrigalion water used by a continuous, cultivaled cotton monoculture and in integrated cotton-forage-livestock system averaged over 6 years (1999 through 2004).

and livestock and under the described input conditions, profitability of the integraled crop/livestock system was about $90 \%$ greater than that of the monoculture cotton systems (Allen et al., 2005: Table 1). Profitability has been calculated using constant prices for all inputs and commodities during these years. With the change of cotton varieties, yield of cotton increased in both systems after 2002 resulting in an increase in prolitability for both systems with the monoculture cotton system exceeding that of the inlegrated system. Results to date indicate that when all other factors were constant and cotton lint yields exceeded about $1500 \mathrm{~kg} \mathrm{ha}^{-1}$, profitability was greater for the monoculture system. When cotton lint yield were about $1100 \mathrm{~kg} \mathrm{ha}^{-1}$, profitability was greater for the integrated system. The average irrigated (all types of irrigation systems) cotton lint yields in the Texas High Plains during 1997-2004 was $630 \mathrm{~kg} \mathrm{lint} \mathrm{ha}^{-1}$. Thus, most cotton produced in this region is not achieving sufficient productivity to reach this level of profitability. Furthermore, when net relurns over variable costs were calculated per unit of irrigation water used, the integrated system had a higher net return at every pumping depth (Fig. 3). Not only must less total inigation water be used in the future, but the value of the water invested in terms of agricultural commodity prodtced per unit of water must increase as well. The integrated system is accomplishing both of these objectives. Today, if cotton monoculture yields can be incrensed, income in the short run is increased but it carries the cost of increased water pumped from the aquifer, increased soil erosion, decreased soil quality, a higher risk from the lack of diversification, and the likely lack of a long-term future.

\section{Discussion}

With the decline in water in the Ogallala aquifer and the increase in costs of energy required to extract that water, current cropping systems in the Texas High Plains are unlikely to continue into the future as they have during the last century. This research suggests that an integrated approach can conserve more water and improve profitability compared with the monoculture unless cotton yields on average become higher than they are today. Several different types of irrigation are currently practiced in the region ranging from flood inigation to center-pivot systems including low-energy, precision-application (LEPA), as well as subsurface drip technologies. Drip irrigation and LEPA are more efficient than other means of applying water but total water applied by any technology remains greater than the potential to recharge the aquifer. Adoption of these water sivings technologies has allowed more wells to be installed, further depleting the aquifer (Segarra and Feng, 1994). Thus, on a landscape basis, significant areas are likely to revert to dryland agriculture with lower yield potential.

Wholc-farm systems research is limited. Crop rotations have long been known to improve soil quality, fertility, and crop production but inclusion of grazing animals within the rotation has largely not been rescarched. Integrated dryland crop and livestock production systems on the Great Plains have been suggested to be an ecologically and economically sustainable form of agriculture but the systems will be agriclimatic zone specific (Krall and Schuman, 1996). In the agriclinnatic zone of the Llano Estacado, successful systems will likely be based on warm-season perennial grasses that can maintain reasonable productivity under limited irrigation or dryland conditions. The native grass species and the introduced Bothriochloa species appear suited to this with $B$. caucasica and $B$. blathii producing more biomass than $B$. ischaemum spp. (Philipp, 2004). The cool-season small grains provided high quality fornge that supported excellent animal gains but were economically more costly than the warm-season perennial grass in our research. The lower water use efficiency and lower heat tolerance of cool-season perennial grasses make their extensive use unlikely in this region. Additional systems must be tested with other forage species and under dryland conditions to expand opportunities for water and soil conservation while maintaining a viable economy.

The reduction in $\mathrm{N}$ fertilizer use by the integrated system is particularly important in reducing energy requirements of the system. While almost every aspect of agriculture carries an energy cost, nitrogen fertilizer is one of the most energy expensive (Whitehead, 1995). Legumes, well known for their associntion with Rhizobia bacteria and atmospheric $\mathrm{N}$ fixation, are not widely used in the Texas High Plains because of their higher waler requirements. Alfulfa (Medicago sativa), well adapled to the climate and soils, has a transpirntion ratio ( $\mathrm{kg}$ of water per $\mathrm{kg}$ of dry matter produced) of over 800 (Martin et al., 1976). The trinspirition ratio of red clover (Trifolium pratense) is about 700 while bermudagrass (Cynodon dactylon) and sorghum (Sorghtun bicolor) have transpiration ratios of about 270 (Martin et al., 1976). Cotton also requires about 
$270 \mathrm{~kg}$ of water to produce $1 \mathrm{~kg}$ of cotton lint (Lascano et al., 1994). With the dependence in this region on high-value, water use efficient plants that do not fix atmospheric $N$, management of $\mathrm{N}$ fertilizers takes on added importance.

Diversity has been suggested as the foundation of sustainable cropping systems to reduce risks of pests and diseases and to reduce the negative impacts of agricultural chemicals (Cutforth et al., 2001). A primary impediment to diversifying the cropping and livestock systems in the Texas High Plains has been the economies of scale realized through the specialization of cotton production and cattle on feedyards and the costs of associnted infrastructures. Further factors that may slow aldoption include tradition, producer experience, and willingness to learn new technologies but rapidly escalating costs of energy and declining water supplies are already causing such changes to occur.

\section{Conclusions}

Although this long-term research will be continued, five demonstrable impacts are emerging that have great signilicance. They are as follows:

(1) Systems can be designed that do use less water than the cotton monoculture typical of this region. The current system being tested uses about $23 \%$ less irrigation water than the continuous cotton. This difference has been consistent across both exceptionally dry and exceptionally wet years. Indications are that further refinements in the system design could potentially lead to further reductions in water use.

(2) Results to date indicate that the integrated system possesses a higher net return above variable costs per ha than the irrigated cotton monoculture at levels of productivity typical of the Texas High Plains [630 kg lint ha ${ }^{-1}$ : irrigated cotton-all types (19972004)]. Furthermore, the integrated system continued to be more profitable than the cotton monoculture at levels of production up to about $1100 \mathrm{~kg} \mathrm{lint} \mathrm{hal}$ but by $1500 \mathrm{~kg}$ lint hn $\mathrm{h}^{-1}$ the monoculture cotton system in this research was more profitable. Profitability of the integrated system in terms of net returns per unit of water used was greater than that of the cotton monoculture at all levels of lint production.

(3) Grazing systems can be designed for the Southern High Plains that will support at least average or above average levels of animal performance. Results of our research suggest that this could be done on water use efficient perennial grass pastures.

(4) Irrigated small grain foriges are expensive for grazing livestock in this region. While these are high quality forages and provide needed protein, their cost in terms of water, labor, seed, and chemicals does not appear to justify their use if alternatives can be found. If their intended purpose is grain production and some grazing can be accomplisbed without reducing grain yield, then their use for grazing may be justified, but this needs further careful evaluation.

(5) While this research demonstrates advances made in designing systems that are more protective of water resources, further improvements are essential if agriculture is going to be sustainable on the Llano Estacado. Such systems appear possible, but will require whole systems research approaches that include the sociological as well as the environmental and economic aspects of implementation.

The Llano Estacado region of Texas evolved though millions of years to a relatively stable grassland ecosystem. Twelve thousand years of occupation by Native Americans did have measurable effects but their activities were largely in balance with the environment in ways that were sustainable over these thousands of years. Intensive agriculture imposed on this region during the last 100 years bas altered dramatically this balance and has been consumptive of natural resources at a rate that is not sustainable. The future of this region in terms of continued agricultural potential depends on development of alternative practices that are more in concert with the environment, the economy, and the willingness of the people of the region to adopt alternative practices. It is likely that the future will involve greater diversity in crop and livestock systems with less dependence on monocultures in order to lower risk and conserve resources. New and creative approaches will be required to meet the challenges of the future.

\section{Acknowledgements}

Supported in part by grants from the USDA-Sustainable Agriculture Research and Education, Southern Region, Griffin, Georgia and the High Plains Underground Water Conservation District No. 1, Lubbock. Texas. Approved by the Dean of the College of Agriculture and Natural Resources, Texas Tech Univ. Publ. No. T-4565. Received. In addition to the authors listed, numerous other individuals contribute to this research and include faculty, students, industry personnel, producers, and government agencies. Their contributions are recognized and appreciated.

\section{References}

Acostn-Martinez, V., Zobecti, T.M., Allen, V.G., 200-4. Soil microbial, chemical and plysical properties in continuous cotton and integrated crop-livestock systems. Soil Sci. Suc. Am. J. 68, 1875-1884.

Allen, V.G., Brown, C.P., Kellison, R., Segarra, E., Wheeler, T., Dutray, P., Conkwright, J., Green, C., Acosta-Martinez, V., 2005. Integrating cotton and beef production to reduce water withdrawal from the Oyallala Aquifer in the Southern High Plains. Agron. J. 97, 556-567.

Allen, V.G., Daniels, W.L., Evanylo, G., Fontenot, J., Laub, C., Taylor, D., Vaughan, D., Youngman, R., Znjac, A., 1994. Susiainable crop and 
livestock systems for the Southeastern Utited States. 1994 Progress Report. Virginin Tech, $49 \mathrm{pp}$.

Allen, V.G., Fontenot, J., Daniels, W.L., Zaijac, A., Evanylu, G., Youngmsan, R., Luna, J., 1997. Sustainable and conventional grazing systemis for beef steers. In: Proc. XVIII International Grassiand Congress, Section 19:17-18, Cannda.

Allen, R.G., Pereira, L., Rnes, D., Smith, M., 1998. Crop evapotranspiration. FAO Utigation and Drainese Paper 56. FAO, Ronte, ftaly.

Brooks, E., Enel, J., Jokisch, B., Robbins, P., 2000. The Llano Estncado of the US Soutlern High Plains: Envisonmental Transformation and the Prospect for Sustainability. United Nations University Press, New York.

Collins, J., 2003. Agricultural phosphons in an integrated crop/livestock system in the Texas High Plains. M.S. Thesis. Texas Tech University, Lubbuck.

Cutforth, L.B., Francis, C.A., Lynne, G.D., Morteasen, D.A., Eskridge, K.M., 2001. Facturs alfecting fnrmers' crop diversity decisions: an integrated approach. Am. J. Alt. Agric. 16, 1688-2176.

Duch-Carvallo, T., 2005. WW-B. Dahl old world bluestem [Bothriochloa hlalhii (RETZ.). S.T. Blake] in sustainahle systems for the Texas Fligla Plains. Pl.D. Dissertaliun. Texas Tech University, Lubbock.

EWRI, 2001. The ASCE Standardized Reference Evapotranspiration Equation. EWRI of ASCE. Reston, VA. Available at http://www.kimberly.uidaho.edu/water/asceewri/main.pd (verified lo December 2005, online).

Fontenot, J.P., Allen, V.G., Scutt, L.L., Vauglan, D.H., Laub, C.A., Taylor, D.B. 1997. Sustainable and conventional grazing systems for beef steers. In: Proc. XVHI Iaternational Grassland Congress, Section 19:33-34, Canada.

Fryrear, D.W., Sutterland, P.L., Davis, G., Hurdee, G., Dollar, M., 2001. Wind erusion estimates with RWEQ and WEQ. In: Stott, D.E., Mohtar, R.H., Steinlarul, G.C. (Eds.), Sustaining the Global Farm. Proc. Int. Soil Conserv, Org. Meding, 10th, Purdue University, West Lafayette, IN. 25 May 1999. Ini. Soil Cunserv. Org., USDA-ARS Natl. Soil Erosion Res. Lat. and Purdue Univ., West Lafayette, gp. $760-765$.

Gould, F.W., 1975. The Grasses of Texuss. Texas A\&M University Press, College Strtion, Texas.

Gutentag, E.D., Hetmes, F.J., Krothe, N.C., Lucky, R.R., Weeks, J.B., 1984. Geohydrology of the ligh plaiss aquifer in parts of Colorado, Kansas, Nebraska, New Mexicu, Oklalomn, South Dakotn, Texas and Wyoming. USGS Professional Paper 1401)-B. U.S. Government Printing Office, Washington, DC.

High Plains Underground Water Conservation District No. 1, 2003. Depthto-water level measurements in disirict observation well network teveal average ground water level destine of 1.06 feet during 2002 . The Cross Section 49(4):1.

Hyde, G., 1959. Indians of the High Plains: From the Prehisturic Period to the Conuing of the Europeans. Oklahoma Press, Norman, Oklahoma.

Izzand, B., 1993. Adobe Walls Wars. Tanglaire Press, Amarillo, Texas.
Jolınson, E, 1931. The Natural Regions of Texas, University of Texas Bulletin No. 1113. Universily of Texas Press, Austin, Texas.

Krall, J.M., Scluman, G.E., 1996. Integrated dryland ctop and livestock production systems on the Grest Plains. Extent Outlook. J. Prodn. Agric. 9, 187-191.

Lascano, R.J., Baumhardt, R.L., Hicks, S.K., Heilman, J.L., 1994. Soil and plant water evaporation from strip-tilled cotton: measurement and simulalion. Agron. J. 86, 987-994.

Lee, J.B., Allen, L., Peterson, R.E., Gregury, J.M., Moffet, K.E., 1994. Environmental controls on blowing dust direction at Lubhock, Texas. U.S.A. Earth Surf. Proc. Londf. 19, $427-449$

Livingston, R.B., 1952. Relict true prairie communifies in central Colorado. Ecology 33, 72-86.

Martin, J.I., Leuaard, W.I., Stamp, D.L., 1976. Principles of Field Crop Production. Macmillan Publishing Co., Ine., New York.

Maupin, M.A., Barber, N.L., 2005. Estimaled witludrawals from principal aquifers in the United States, 2000. U.S. Gevlogical Survey Circular 1279. U.S. Geolotical Survey, Reston, VA.

Morris, J.L., Allen, V.G., Vaughan, D.H., Lunn, J.M., Cochran, M.A., 1998. Establishment of corn in rotation with alfalfa and rye: Influence of grazing, tillnge, and herbicides. Agron. J. 90, 837-844.

Noyes, S., 1993. Los Comanches; The Horse People 1751-1845. University of New Mexico Press, Albuquerque, New Mexico.

Philipp, D., 2004. Influence of varying replacement of potential evapotranspiration on water use efficiency and nutritive value of three old world hluestems (Botlriochloa spp.). Dissertalion. Texas Tech University, Lubbuck, Texas.

Segarra, E., Feng. Y., 1994. Irigation teilnology adoption in the Texns High Plains. Tex. J. Agric, Nat. Res. 7 (1), 71-83.

Steel, R.G.D., Torrie, J.H., 1960. Pritciples and Procedures of Statistits. McGraw-Hill Book Company, Lnc., NY.

[TASS] Texas Agricultural Statistics Service, 1999. 1998 Texas Livestocl Statistics. USDA and the Texas Department of Agriculture, Austin, TX.

USDA National Agricultural Statistics Service, 2003. 2003 Agricultural Statistics. U.S. Gov. Printing Office, Waslington, DC.

Urban, L.V., 1992. Texas high plains. In: Kromm, D.E., White, S.E. (Eds.), Groundwater Exploilation in the High Plains. University Press of Kansas, Lawrence, KS.

Wetb, W.P., 1931. The Great Plains. Ginn and Co., New York, NY.

Weeks, J.B., Gutentng, E., 1984. The higlt plains regional aquifer-geohydrology. In: Whetstone (Eds.), Proeecdings of the Ogallala Aquifer Symposium II. Water Resourees Center. Texas Tecl University, Lubhock, Texas.

Weeks, J,B., Sun, R.J., 1986. High plains regional aquifer study, in: Sun, R.J. (Ed.), Regional Aquifer-System Analysis Program of the U.S. Geolotical Survey of Projects, 1978-1984. U.S. Geological Survey Circular 1002. U.S. Govemment Printing Oflice, Washington, DC.

Whitelead, D.C., 1995. Grassland Nitrogen. CAB International, Biddles Ltd., Guildford, UK. 